\title{
Review
}

\section{Present Algorithms and Future Treatments for Alzheimer's Disease}

\author{
George T. Grossberg ${ }^{\mathrm{a}, *}$, Gary Tong ${ }^{\mathrm{b}}$, Anna D. Burke ${ }^{\mathrm{c}}$ and Pierre N. Tariot ${ }^{\mathrm{d}}$ \\ ${ }^{\mathrm{a}}$ St. Louis University School of Medicine, St. Louis, MO, USA \\ ${ }^{\mathrm{b}}$ Lundbeck, Deerfield, IL, USA \\ ${ }^{\mathrm{c}}$ Barrow Neurological Institute, Phoenix, AZ, USA \\ 'Banner Alzheimer's Institute, Phoenix, AZ, USA
}

Handling Associate Editor: Anne Fink

Accepted 21 December 2018

\begin{abstract}
An estimated 47 million people live with Alzheimer's disease (AD) and other forms of dementia worldwide. Although no disease-modifying treatments are currently available for AD, earlier diagnosis and proper management of the disease could have considerable impact on patient and caregiver quality of life and functioning. Drugs currently approved for $\mathrm{AD}$ treat the cognitive, behavioral, and functional symptoms of the disease and consist of three cholinesterase inhibitors (ChEIs) and the N-methyl-D-aspartate receptor antagonist memantine. Treatment of patients with mild to moderate AD is generally initiated with a ChEI. Patients who show progression of symptoms while on ChEI monotherapy may be switched to another ChEI and/or memantine can be added to the treatment regimen. In recent years, putative disease-modifying therapies have emerged that aim to slow the progression of AD instead of only addressing its symptoms. However, many therapies have failed in clinical trials in patients with established $\mathrm{AD}$, suggesting that, once developed, disease-modifying agents may need to be deployed earlier in the course of illness. The goal of this narrative literature review is to discuss present treatment algorithms and potential future therapies in $\mathrm{AD}$.
\end{abstract}

Keywords: Algorithm, Alzheimer's disease, cholinesterase inhibitors, memantine, treatment

\section{INTRODUCTION}

Alzheimer's disease (AD) is a slowly progressive neurodegenerative disorder and the leading cause of dementia [1]. Approximately 50 million people live with $\mathrm{AD}$ and other forms of dementia worldwide, and the number of cases is estimated to quadruple by $2050[2,3]$. Reflecting the overall aging of the global

\footnotetext{
${ }^{*}$ Correspondence to: George T. Grossberg, MD, Department of Psychiatry \& Behavioral Neuroscience, St. Louis University School of Medicine, 1438 South Grand Blvd, St. Louis, MO 63104, USA. Tel.: +1 314977 4825; Fax: +1 314977 4876; E-mail: George.Grossberg@health.slu.edu.
}

population, a Canadian population health modeling study for neurological diseases projected a 2 -fold increase in the number of people living with dementia by 2031 [4]. AD has a sizable public health impact, and it is estimated that patients with dementia cost the healthcare system over $300 \%$ more than their cognitively intact peers in the same age group [5]. Furthermore, the impact of this disease has increased considerably during the past 2 decades; $\mathrm{AD}$ was the sixth leading cause of death in 2012 in the United States $[5,6]$. In addition to causing disability and health problems for patients, $\mathrm{AD}$ may also place a substantial burden on caregivers [3]. 
There is a need for improved identification of individuals who may be developing AD. Most patients with $\mathrm{AD}$ routinely see their primary care physician, but most practitioners lack practice models to identify and treat patients with AD [7]. As few as $20 \%$ of Americans with AD are diagnosed with the condition, and $50 \%$ are exposed to inappropriate medications, with only $7 \%$ receiving cholinesterase inhibitors (ChEIs) [8-10]. Although there are no available disease-modifying treatments for $\mathrm{AD}$, the currently approved therapeutic agents show benefits on measures of cognition, behavior, and daily function and include three ChEIs and one N-methylD-aspartate (NMDA) receptor antagonist [11]. However, even though these treatments are currently available, results from a recent real-world retrospective analysis of treatment patterns in the United States showed that approximately $57 \%$ received antidementia treatment after initial AD diagnosis, and approximately $52 \%$ of those initiating monotherapy with one of these agents continued treatment during the follow-up time period with approximately $22 \%$ discontinuing and remaining untreated [12]. A study assessing the effects of drug coverage policy on persistence and risk of discontinuation of ChEIs in new (post-policy change) versus old (pre-policy change) patients with dementia or AD in British Columbia found that persistence was significantly prolonged in new patients after the government began covering the cost of these agents [13]. Discontinuation rates were also lower for new versus old patients. Although it is unknown whether this positive change resulted from lower out-of-pocket fees, or new policy mandated follow-up visits and physician education programs, the finding demonstrates that healthcare policy changes can be beneficial in increasing drug utilization in patients with dementia [13].

The objective of this narrative review is to discuss current treatment algorithms and potential future therapies for the treatment of AD.

\section{CHOLINESTERASE INHIBITORS}

The three ChEIs currently approved for the treatment of AD in the United States are donepezil [14], galantamine [15], and rivastigmine [16] (Table 1). Tacrine, the first ChEI approved for the treatment of $\mathrm{AD}[11,17]$, has been discontinued in the United States because of an association with hepatotoxicity and is not included here [18]. The currently approved indications and dosage information for ChEIs are listed in (Table 1).

Decreased cholinergic function is linked to cognitive impairment in patients with $\mathrm{AD}[11,19]$. ChEIs function by restoring the cholinergic pathway via their binding to, and inhibiting, acetylcholinesterase (AChE), and to a lesser extent butyrylcholinesterase (BuChE), thereby increasing the levels of acetylcholine at the synapse and presumably prolonging its physiological effect [11, 20, 21].

Donepezil is a reversible, noncompetitive ChEI that was approved in 1996 in the United States [14]. It is metabolized in the liver and has the longest halflife of the ChEIs (approximately 60 hours in young volunteers and $>100$ hours in elderly patients) [22]. Donepezil is currently approved for mild, moderate, and severe AD and is available as regular and orally disintegrating tablets; donepezil oral solution was discontinued in the United States [14]. More recently, a higher-dose donepezil formulation ( $23 \mathrm{mg} /$ day) was approved for the treatment of moderate to severe AD based on a large, randomized, double-blind study $(\mathrm{N}=1,434)$ that demonstrated significantly greater improvements in cognition with donepezil $23 \mathrm{mg}$ versus $10 \mathrm{mg}$ at week 24 , without improvement in measures of global status [23]. Adverse events (AEs), mostly gastrointestinal, were also reported at a higher frequency in the $23 \mathrm{mg}$ group than in the $10 \mathrm{mg}$ group [23].

Rivastigmine is an intermediate-acting, pseudoirreversible, noncompetitive $\mathrm{ChEI}$ that inhibits BuChE with similar potency $[19,20]$. It was approved by the United States Food and Drug Administration (FDA) in 2000 and is indicated for the treatment of mild, moderate, and severe Alzheimer-type dementia [16]. Unlike donepezil and galantamine, rivastigmine is not metabolized by the liver, making it more suitable for patients with renal or hepatic impairment [11]. Rivastigmine is available as an oral capsule (1.5, $3,4.5$, and $6 \mathrm{mg})$, oral solution $(2 \mathrm{mg} / \mathrm{mL})$, and transdermal patch $(4.6,9.5$, and $13.3 \mathrm{mg} / 24 \mathrm{~h}$; Table 1) $[16,24]$. The $9.5 \mathrm{mg} / 24 \mathrm{~h}$ patch and the $6 \mathrm{mg}$ twicedaily oral dose provide similar exposure, although fluctuations in maximum concentration $\left(\mathrm{C}_{\max }\right)$ and minimum concentration $\left(\mathrm{C}_{\min }\right)$ are less for the patch than with the oral formulation, which may result in a more favorable safety and tolerability profile with the patch [24-26]. Exposure is highest when the patch is applied to the upper back, chest, or upper arms; plasma exposure is approximately $20 \%$ to $30 \%$ lower when applied to the abdomen or thigh [27]. 
Table 1

Currently approved therapies for $\mathrm{AD}$

\begin{tabular}{lllll}
\hline & Donepezil HCl [14] & Rivastigmine [16, 24] & Galantamine HBr [15] & Memantine [43] \\
\hline Class & ChEI & ChEI/BuChEI & ChEI & NMDA receptor antagonist \\
US approval & 1996 & 2000 & 2001 & ChEI and NMDA receptor antagonist \\
combination
\end{tabular}

Available forms Tablets: 5,10 , and $23 \mathrm{mg}$ ODT: 5 and $10 \mathrm{mg}$

Indications

Treatment of mild, moderate, and severe Alzheimer-type dementia

Capsules: $1.5,3,4.5$, and $6 \mathrm{mg}$ Oral solution: $2 \mathrm{mg} / \mathrm{mL}$

ER capsules: 8,16 , and $24 \mathrm{mg}$ TD patch: $4.6,9.5$, and $13.3 \mathrm{mg} / 24 \mathrm{~h}$ Oral solution: $4 \mathrm{mg} / \mathrm{mL}$

Treatment of mild to moderate (all Treatment of mild to moderate formulations) and severe (patch Alzheimer-type dementia

only) Alzheimer-type dementia an mild to moderate dementia associated with PD

Dosage

5-10 mg QD (mild to moderate) Capsule/oral solution: initial 10-23 mg QD (moderate to severe) treatment $1.5 \mathrm{mg}$ BID, thereafter

3-6 $\mathrm{mg}$ as tolerated BID Tablets and oral solution: starting

dose $4 \mathrm{mg}$ BID, thereafter $8-12 \mathrm{mg}$

thereafter $9.5-13.3 \mathrm{mg} / 24 \mathrm{~h}$

ER capsules: 7, 14, 21, and $28 \mathrm{mg}$ Tablets: 5 and $10 \mathrm{mg}$

Oral solution: $2 \mathrm{mg} / \mathrm{mL}$

Treatment of moderate to severe Alzheimer-type dementia

ER capsules: 7, 14, 21, and $28 \mathrm{mg}$ memantine with $10 \mathrm{mg}$ donepezil

Treatment of moderate to severe Alzheimer-type dementia in patient stabilized on $10 \mathrm{mg}$ donepezil hydrochloride QD

ER capsules: starting dose $8 \mathrm{mg}$ QD, ER capsules: starting dose $7 \mathrm{mg}$ QD, Starting dose $7 \mathrm{mg} / 10 \mathrm{mg}$ QD, thereafter increase $7 \mathrm{mg}$ increments thereafter increase memantine $7 \mathrm{mg}$ up to maintenance dose of $28 \mathrm{mg} \quad$ increments up to maintenance dose of QD; in patients with severe renal $\quad 28 \mathrm{mg} / 10 \mathrm{mg}$ QD; in patients with impairment, recommended dose is severe renal impairment, $14 \mathrm{mg}$ QD

Tablets/oral solution: Starting dose $5 \mathrm{mg}$ QD, thereafter increase $5 \mathrm{mg}$ increments to maintenance dose of $10 \mathrm{mg}$ BID; in patients with severe renal impairment, recommended dose is $5 \mathrm{mg}$ BID

Drug interactions

May interfere with the activity of anticholinergic medications possible synergistic effect with concomitant administration of succinylcholine, similar

neuromuscular blocking agents, or cholinergic agonists

Concomitant use with metoclopramide, $\beta$-blockers, or cholinomimetic and anticholinergic drugs is not recommended

May interfere with the activity of anticholinergic medications; a possible synergistic effect with concomitant administration of succinylcholine, other ChEIs, similar neuromuscular blocking agents, or cholinergic agonists

Nausea, diarrhea, insomnia, vomiting, muscle cramps, fatigue, and anorexia

Nausea, vomiting, anorexia, dyspepsia, diarrhea, and asthenia

Nausea, vomiting, diarrhea, dizziness, headache, and decreased appetite

Concomitant use with drugs that make urine alkaline (e.g., carboni anhydrase inhibitors, sodium bicarbonate) and other NMDA antagonists (e.g., amantadine,

ketamine, dextromethorphan) is not recommended

Headache, diarrhea, and dizzines

May interfere with the activity of anticholinergic medications; possible synergistic effect with oncomitant administration of succinylcholine, similar

euromuscular blocking agents, or cholinergic agonists; use caution with other NMDA antagonists

Headache, diarrhea, and dizzines (memantine); diarrhea, anorexia, vomiting, nausea, and ecchymosis (donepezil)

AD, Alzheimer's disease; AE, adverse event; BID, twice daily; BuChEI, butyrylcholinesterase inhibitor; ChEI, cholinesterase inhibitor; ER, extended release; HBr, Hydrobromide; $\mathrm{HCl}$, Hydrochloride; NMDA, N-methyl-D-aspartate; ODT, orally disintegrating tablet; PD, Parkinson's disease; QD, once daily; TD, Transdermal. 
Galantamine is a short-acting, reversible, competitive ChEI that was approved in 2001 in the United States for mild to moderate AD [11, 15, 20]. Galantamine is available in three formulations, extended-release (ER) capsules, tablets, and oral solution, which differ slightly in their pharmacokinetics [15]. The ER capsules and tablets are bioequivalent for the area under the concentrationtime curve from 0 to $24 \mathrm{~h}$ and $\mathrm{C}_{\min }$; however, $\mathrm{C}_{\max }$ of the ER capsule is $25 \%$ lower, and time to $\mathrm{C}_{\max }$ occurs in 4.5 to $5.0 \mathrm{~h}$ after administration compared with 7.0 to $8.0 \mathrm{~h}$ with the tablets $[11,15]$. The bioavailability of the tablet formulation is equivalent to the oral solution formulation [15].

All three ChEIs appear to improve global, cognitive, and functional outcomes (Table 2) [28-30]. A meta-analysis of 23 ChEI clinical studies demonstrated significant benefits on the Alzheimer's Disease Assessment Scale cognitive subscale (ADAS-cog) with 5 and $10 \mathrm{mg}$ donepezil (mean difference versus placebo, -1.95 and -2.48 , respectively; $p<0.00001), 24$ and $32 \mathrm{mg}$ galantamine $(-3.03$ and -3.20 , respectively; $p<0.00001)$, and $12 \mathrm{mg}$ rivastigmine $(-2.01 ; p<0.00001)$ versus placebo in mild to moderate AD [28]. Similar results were observed in two other meta-analyses (Table 2) $[29,30]$. Weighted mean differences (ChEIs versus placebo) from individual studies varied from -2.12 to -3.20 for donepezil 5 and $10 \mathrm{mg}$, from -1.6 to -3.96 for galantamine 24 and $32 \mathrm{mg}$, and from -1.6 to -4.6 for rivastigmine 6 to $12 \mathrm{mg}$ [31]. Donepezil also demonstrated significant cognitive benefits over placebo in severe AD [32]. Treatment with ChEIs is usually associated with a favorable impact on global measures and mixed results on functional measures; effects on behavioral outcomes have been inconsistent $[28,29]$. However, these behavioral analyses were mostly based on studies that enrolled patients with mild to moderate $\mathrm{AD}$, which may have resulted in a less agitated population. Despite this observation, most experts favor deploying these agents first (and/or memantine) when clinically appropriate and assessing whether benefit for behavioral features is clinically discernible before deploying other classes of agents [33].

Evidence regarding time to institutionalization is mixed. Long-term use of ChEIs resulted in delayed nursing home placement in three observational studies, whereas no difference versus placebo in time to institutionalization or progression of disability was noted in the randomized controlled AD2000 study of donepezil [34-37]. Long-term treatment with donepezil (1 year) was also associated with reduced risk of functional decline versus placebo [38]. Furthermore, a long-term study in patients with possible or probable $\mathrm{AD}$ demonstrated that a 1-year delayed start of donepezil treatment resulted in greater global deterioration and significantly worsened cognitive function compared with earlier treatment [39].

Gastrointestinal disturbances are the most common AEs associated with ChEIs [28, 29]. A meta-analysis demonstrated that all three drugs significantly increased the risk of dizziness, nausea, anorexia, vomiting, and diarrhea versus placebo; donepezil and rivastigmine also significantly increased the risk of headache over placebo [28]. Agent-specific AEs considered very common $(>10 \%)$ included diarrhea, headache, and nausea with donepezil; nausea and vomiting with galantamine; and diarrhea, dizziness, anorexia, nausea, and vomiting with oral rivastigmine [40]. Other commonly reported AEs (1\%-10\%) included abdominal pain/disturbance and fatigue with all three ChEIs; anorexia, dizziness, and insomnia with donepezil and galantamine; and asthenia, headache, and somnolence with galantamine and oral rivastigmine [40]. Use of ChEIs may also be associated with urinary incontinence and subsequent initiation of urinary anticholinergic medications; use of urinary anticholinergics can decrease the efficacy of ChEIs and should be avoided in favor of alternative treatments for urinary incontinence [41]. Other possible side effects include muscle cramps, bradycardia, rhinitis, and vivid dreams [40,42]. The rivastigmine oral and patch formulations differ slightly in the type and frequency of AEs, and the patch is associated with lower incidence of gastrointestinal AEs [25, 26, 40]. Commonly reported AEs $(1 \%-10 \%)$ with the rivastigmine patch include anorexia, anxiety, abdominal pain, and application site reactions such as dermatitis, erythema, and irritation [40].

\section{N-METHYL-D-ASPARTATE RECEPTOR ANTAGONIST}

The voltage-dependent NMDA receptor antagonist memantine was approved in 2003 for the treatment of moderate to severe AD [43]; results from mild AD trials did not show consistent or robust benefit [44]. The currently approved indications and dosages for memantine are listed in (Table 1). Memantine may block the effects of excessive glutamate stimulation at the NMDA receptor, thereby preventing 
Table 2

Mean difference between ChEIs, memantine, and placebo in cognitive, global, functional, and behavioral outcomes from meta-analyses of clinical trials

\begin{tabular}{|c|c|c|c|c|c|}
\hline & & $\begin{array}{l}\text { Cognitive Function } \\
\text { (ADAS-cog or SIB) }\end{array}$ & $\begin{array}{c}\text { Global } \\
\text { (CIBIC-Plus or CDR) }\end{array}$ & Function & $\begin{array}{l}\text { Behavior } \\
\text { (NPI) }\end{array}$ \\
\hline \multicolumn{6}{|l|}{ Monotherapy versus placebo } \\
\hline Tan et al. [28] 23 trials; patients with & Donepezil $5 \mathrm{mg}$ & $-1.95(-2.60 \text { to }-1.29)^{* * *}$ & ND & $1.00(-0.53$ to 2.53$)$ & ND \\
\hline \multirow[t]{5}{*}{ mild, moderate, or severe AD } & Donepezil $10 \mathrm{mg}$ & $-2.48(-3.23 \text { to }-1.73)^{* * *}$ & ND & $1.03(0.21 \text { to } 1.85)^{*}$ & $-2.72(-4.92 \text { to }-0.52)^{*}$ \\
\hline & Galantamine $24 \mathrm{mg}$ & $-3.03(-3.66 \text { to }-2.41)^{* * *}$ & ND & $0.68(0.04 \text { to } 1.32)^{*}$ & $-1.72(-3.12 \text { to }-0.33)^{*}$ \\
\hline & Galantamine $32 \mathrm{mg}$ & $-3.20(-4.36 \text { to }-2.04)^{* * *}$ & ND & ND & ND \\
\hline & Rivastigmine $12 \mathrm{mg}$ & $-2.01(-2.69 \text { to }-1.32)^{* * *}$ & ND & $1.80(0.20 \text { to } 3.40)^{*}$ & $-0.50(-2.68$ to 1.68$)$ \\
\hline & Memantine $20 \mathrm{mg}$ & $-1.29(-2.30 \text { to }-0.28)^{*}$ & ND & $1.02(0.27 \text { to } 1.78)^{* *}$ & $-0.71(-1.98$ to 0.55$)$ \\
\hline \multirow{4}{*}{$\begin{array}{l}\text { Birks [30] } 13 \text { trials; patients with } \\
\text { mild, moderate, or severe AD }\end{array}$} & ChEIs pooled ${ }^{\mathrm{a}}$ & $-2.37(-2.73 \text { to }-2.02)^{* * *}$ & $1.84(1.47 \text { to } 2.30)^{* * *}$ & $2.46(1.55 \text { to } 3.37)^{* * *}$ & $-2.44(-4.12 \text { to }-0.76)^{* *}$ \\
\hline & Donepezil $^{\mathrm{b}}$ & From: -2.33 to -2.92 & From: 1.62 to 2.08 & 3.80 & From: 2.60 to -5.60 \\
\hline & Galantamine $^{\mathrm{b}}$ & From: -2.90 to -3.90 & ND & ND & -2.00 \\
\hline & Rivastigmine $^{\mathrm{b}}$ & From: -1.10 to -1.60 & ND & From: 0.80 to 3.40 & ND \\
\hline \multirow{3}{*}{$\begin{array}{l}\text { Hansen et al. [29] } 22 \text { trials; patients } \\
\text { with mild, moderate, or severe AD }\end{array}$} & Donepezil pooled $^{\mathrm{c}}$ & $-2.67(-3.28 \text { to }-2.06)^{\mathrm{n} p}$ & ND & $0.31(0.21 \text { to } 0.40)^{\mathrm{np}}$ & $-4.3(-5.95 \text { to }-2.65)^{\mathrm{np}}$ \\
\hline & Galantamine pooled ${ }^{c}$ & $-2.76(-3.17 \text { to }-2.34)^{\mathrm{np}}$ & ND & $0.27(0.18 \text { to } 0.36)^{\mathrm{np}}$ & $-1.44(-2.39 \text { to }-0.48)^{\mathrm{np}}$ \\
\hline & Rivastigmine pooled $^{\mathrm{c}}$ & $-3.01(-3.80 \text { to }-2.21)^{\mathrm{np}}$ & ND & $0.26(0.11 \text { to } 0.40)^{\mathrm{np}}$ & ND \\
\hline \multicolumn{6}{|l|}{ Combination versus ChEI monotherapy } \\
\hline $\begin{array}{l}\text { Schmidt et al. [69] } 4 \text { trials; patients } \\
\text { with moderate or severe AD }\end{array}$ & Memantine + ChEI & $-0.27(-0.37 \text { to }-0.17)^{* * *}$ & $-0.20(-0.31 \text { to }-0.09)^{* * *}$ & $-0.08(-0.18$ to 0.02$)$ & $-0.19(-0.31 \text { to }-0.07)^{* *}$ \\
\hline $\begin{array}{l}\text { Matsunaga et al. [68] } 7 \text { trials; patients } \\
\text { with mild, moderate, or severe AD }\end{array}$ & Memantine + ChEI & $-0.13(-0.26$ to 0.01$)$ & $-0.15(-0.28 \text { to }-0.01)^{*}$ & $-0.10(-0.19 \text { to }-0.01)^{*}$ & $-0.13(-0.24 \text { to }-0.02)^{*}$ \\
\hline $\begin{array}{l}\text { Tsoi et al. [71] } 14 \text { trials; patients } \\
\text { with mild, moderate, or severe AD }\end{array}$ & Memantine + ChEI & ND & $0.01(-0.25$ to 0.28$)$ & $-0.14(-1.23$ to 0.95$)$ & $-1.85(-4.83$ to 1.13$)$ \\
\hline \multicolumn{6}{|c|}{ Combination versus memantine monotherapy } \\
\hline $\begin{array}{l}\text { Tsoi et al. [71] } 14 \text { trials; patients } \\
\text { with mild, moderate, or severe AD }\end{array}$ & Memantine + ChEI & ND & ND & $-0.39(-1.01$ to 0.23$)$ & ND \\
\hline
\end{tabular}

AD, Alzheimer's disease; ADAS-cog, Alzheimer's Disease Assessment Scale cognitive subscale; CDR, Clinical Dementia Rating scale; ChEI, cholinesterase inhibitor; CIBIC-Plus, Clinician's Interview-Based Impression of Change Plus caregiver input; ND, not determined; NPI, neuropsychiatric inventory; SIB, Severe Impairment Battery. Functional outcomes based on various measures, including Alzheimer's Disease Cooperative Study-Activities of Daily Living, Bristol Activities of Daily Living Scale, and Progressive Deterioration Scale. ${ }^{*} p<0.05 ;{ }^{* *} p<0.01 ;{ }^{* * *} p<0.001 ;{ }^{\text {np No }}$ $p$ value provided. ${ }^{\mathrm{a}}$ Mean doses: donepezil $10 \mathrm{mg}$, galantamine $24 \mathrm{mg}$, and rivastigmine $8.5-10.4 \mathrm{mg}$. ${ }^{\mathrm{b}}$ Range of mean difference in individual studies. ${ }^{\mathrm{c}}$ Dose range in individual studies: donepezil $5-10 \mathrm{mg}$, galantamine $16-32 \mathrm{mg}$, and rivastigmine $6-12 \mathrm{mg}$. 
an excess of downstream calcium influx and oxidative stress $[11,45]$. Elevated tonic glutamate levels in $\mathrm{AD}$ are thought to result from inefficient removal mechanisms at the synaptic cleft [11]. The abnormal buildup of glutamate leads to overactivation of NMDA receptors, with the resulting chronic excitotoxicity possibly contributing to neuronal loss and cognitive impairment $[11,45]$.

Individual clinical trials examining the benefits of memantine on cognitive, global, and functional outcomes have reported mixed results [28, 46-55], but the overall evidence has been sufficient to gain approval for treating patients with moderate to severe $\mathrm{AD}$ and not for milder disease stages. In the pivotal phase III clinical trials, memantine provided benefit (e.g., overall global change, activities of daily living, cognitive performance) in patients with moderate to severe AD when used as monotherapy [52] or in addition to donepezil [53]; however, another monotherapy trial in patients with moderate to severe disease failed to achieve statistical significance in primary or secondary endpoints [54]. In trials in patients with mild to moderate $\mathrm{AD}$, the same extent of benefit has not been seen consistently with memantine (alone or as add-on therapy) [48-51, 55]. The efficacy of memantine therapy has been examined in meta-analyses that demonstrate significantly improved cognitive outcomes (as measured by the Severe Impairment Battery, ADAS-cog, Mini-Mental State Examination [MMSE], or Standardized MMSE in the individual trials) in patients with mild to severe AD (standardized mean difference versus placebo, $-0.27 ; p<0.0001)$ [46] and in patients with mild to moderate $\mathrm{AD}$ (mean difference versus placebo, $-1.29 ; p<0.01$ ) [28]. Memantine therapy was also associated with beneficial effects on global and functional outcomes compared with placebo in patients with mild to severe AD in two meta-analyses [46, 47].

Findings from meta-analyses of memantine's effects on behavioral outcomes have been inconsistent [28, 46, 47]; as with ChEIs, clinicians often assess empirically whether memantine confers clinical benefit before considering use of psychotropics. Although the data presented here are not conclusive, they are encouraging, as memantine treatment appeared to be associated with lower costs, longer time to institutionalization, gains in quality-adjusted life-years [56], and significantly lower incidence of agitation compared with placebo in some studies [46, 47]. Encouraging results from studies on the effectiveness of memantine for reducing agitation may allow for reduced antipsychotic medication use in some patients [57-59]; however, there is currently no Level 1 evidence supporting the use of memantine for agitation.

Memantine is generally well tolerated [60]. Twofold or higher incidences of headache, confusion, and somnolence with memantine versus placebo have been reported [48, 49]. Overall, the most common AEs (1\%-10\%) included constipation, dizziness, headache, hypertension, and somnolence [40]. Because oral clearance is lower and elimination half-life is longer in patients with severe renal impairment, dose reduction in these patients is recommended [61, 62].

\section{COADMINISTRATION OF CHOLINESTERASE INHIBITORS AND N-METHYL-D-ASPARTATE RECEPTOR ANTAGONIST}

Coadministration of memantine and ChEIs has been evaluated in several trials [51, 53, 63-66] and is proposed to have a synergistic effect [19]. A fixed combination of memantine and donepezil in a capsule form was approved in 2014 for moderate to severe AD (Table 1) [67]. The recommended dose of the combination treatment is $28 \mathrm{mg}$ memantine $\mathrm{XR}$ and $10 \mathrm{mg}$ donepezil once daily. The use of memantine and donepezil in combination is bioequivalent to coadministration of individual memantine ER capsules and donepezil [67].

Generally, current evidence suggests but does not definitively prove significant benefits with memantine and ChEI combination therapy over ChEI monotherapy (Table 2) [68-70]. A meta-analysis conducted by the European Academy of Neurology (EAN) found evidence supporting combination therapy over monotherapy in patients with moderate to severe AD [69]. Significant benefits were observed for behavior and mood (standardized mean difference, $-0.19 ; p=0.002$ ), cognitive function $(-0.27 ; p=0.00001)$, and global outcomes $(-0.20$; $p=0.0004)$, but not for activities of daily living $(-0.08 ; p=0.12)$. Similar results were observed in a meta-analysis of seven trials in patients with mild to severe $\mathrm{AD}$ that demonstrated small but significant improvements in behavior (standardized mean difference, $-0.13 ; p<0.03)$, activities of daily living $(-0.10$; $p<0.02)$, and global outcomes $(-0.15 ; p<0.04)$ with combination therapy versus ChEI monotherapy [68]. There were nonsignificant improvements in cognitive 
function $(-0.13 ; p<0.06)$ [68], although these results were not confirmed in a meta-analysis of 14 trials in patients with mild to severe AD [71]. Combination regimens may also delay nursing home admission [72] and be more cost-effective than ChEI monotherapy [73]. A long-term observational study suggested that a combination of memantine and ChEI slowed cognitive and functional decline compared with ChEI monotherapy [74].

\section{CURRENT TREATMENT ALGORITHMS}

The current treatment guidelines for $\mathrm{AD}$ as established by the American Psychiatric Association (APA), the EAN, and the 4th Canadian Consensus Conference on the Diagnosis and Treatment of Dementia are listed in (Table 3) [33, 75, 76]. Of note, the latest recommendations by the American Academy of Neurology (AAN) were published in 2001 [77], before the approval of memantine or the memantine/donepezil combination, and thus are mentioned only briefly in this review.

Therapy should be considered at the time of initial diagnosis of $\mathrm{AD}$ (Fig. 1) [76]. In general, the current treatment guidelines recommend the use of ChEIs for mild to moderate symptoms and memantine or memantine/ChEI combination therapy for moderate to severe symptoms (Table 3) [33, 75-77]. With the approval of the single, once-daily combination formulation of donepezil/memantine, this treatment regimen has become simpler, although the use of memantine and donepezil as two separate prescriptions is still an option. Memantine can also be coadministered with other ChEIs, although clinical trial data are limited [51, 78].

Overall, in patients who show a progression of symptoms while on ChEI monotherapy, consideration should be given to either increasing the dose of their current therapy (if applicable), switching the patient to another ChEI, or adding memantine [79]. Information regarding dosage increases is conflicting. According to the APA 2014 guidelines, there was insufficient evidence to show clinically meaningful advantages of administering higher doses of donepezil [33], although clinicians may consider this on a case-by-case basis provided that close monitoring is performed. However, higher doses of a rivastigmine patch may be associated with greater benefit than lower doses [33]. A 24-week, prospective, randomized, double-blind study in patients with severe $\mathrm{AD}$ found superior effects on cognition and function at weeks 16 and 24 with the $13.3 \mathrm{mg} / 24 \mathrm{~h}$ rivastigmine patch compared with the $4.6 \mathrm{mg} / 24 \mathrm{~h}$ patch [80]. AEs and discontinuations were similar between the groups [80]. Similarly, patients who were switched to the $13.3 \mathrm{mg} / 24 \mathrm{~h}$ patch performed significantly better on functional outcomes compared with those who stayed on the lower $9.5 \mathrm{mg} / 24 \mathrm{~h}$ patch [81]. Although randomized, placebo controlled trials of cholinesterase inhibitors have shown benefit in regards to cognition, behavior, and daily function, as well as a slower rate of decline compared with untreated patients [82], no studies to date of ChEIs or memantine have shown significant reductions in time to conversion to $\mathrm{AD}$ in patients with mild cognitive impairment. This finding is reflected in the recent AAN practice guidelines wherein they recommend that if a clinician chooses to use these agents in a patient with mild cognitive impairment then they must first discuss the lack of clinical efficacy evidence with their patients [83].

Decisions about duration of treatment and therapy discontinuation should be made with care and take into consideration patient needs, comorbidities, presence of AEs, adherence, and effectiveness [75, 79]. In mild to moderate disease, lack of efficacy or presence of AEs should prompt consideration of a switch in therapy [79]. The presence of hallucinations and delusions before discontinuation of ChEIs may predict clinical deterioration [84]. Discontinuation of ChEIs may also be associated with cognitive decline [85-87]; however, antidementia drugs should be discontinued when patients with $\mathrm{AD}$ reach the terminal stage of the disease [75, 79], at which time they usually become eligible for hospice. At this stage, consideration should be given to stopping most, if not all, nonpalliative therapies.

\section{RECOMMENDATIONS FOR THERAPIES FOR NEUROPSYCHIATRIC SIGNS AND SYMPTOMS}

Treatments for neuropsychiatric features are an integral part of $\mathrm{AD}$ management. Estimates are that over time, $>90 \%$ of patients with $\mathrm{AD}$ will develop behavioral/psychiatric changes [88, 89]. Although no agent is currently approved to treat these symptoms in the United States, antidepressants and antipsychotics are commonly used off label in patients with $\mathrm{AD}$. In general, the use of antidepressants (e.g., selective serotonin reuptake inhibitors [SSRIs]) for the treatment of depressive symptoms 
Table 3

Practice guidelines for the treatment of AD

\begin{tabular}{|c|c|c|c|}
\hline & $\begin{array}{l}\text { EAN* Guidelines } 2010 \\
\text { [76] }\end{array}$ & $\begin{array}{l}\text { APA Guidelines } 2014 \\
\text { [33] }\end{array}$ & $\begin{array}{l}\text { CCCDTD4 Recommendations } 2012 \\
\text { [75] }\end{array}$ \\
\hline Mild to moderate AD & $\begin{array}{l}\text { - Consider ChEIs at time of } \\
\text { diagnosis, taking into account } \\
\text { expected therapeutic benefits } \\
\text { and potential safety issues }\end{array}$ & $\begin{array}{l}\text { - Evidence remains modest for efficacy } \\
\text { of ChEIs for mild to moderate AD } \\
\text { - Insufficient evidence to show clinically } \\
\text { meaningful advantages of higher doses } \\
\text { of donepezil } \\
\text { - Higher doses of rivastigmine patch } \\
\text { may be associated with greater benefit }\end{array}$ & $\begin{array}{l}\text { - ChEIs have demonstrated efficacy } \\
\text { and are recommended for most } \\
\text { patients with AD; direct comparisons } \\
\text { do not suggest differences between } \\
\text { agents, and selection will be based } \\
\text { on AE profile, ease of use, } \\
\text { familiarity, and differences between } \\
\text { agents in PK and other MOAs }\end{array}$ \\
\hline
\end{tabular}

Moderate to severe AD $\bullet$ Consider ChEIs at time of diagnosis, taking into account expected therapeutic benefits and potential safety issues

- Consider memantine, taking into account expected therapeutic benefits and potential safety issues

\section{Depression}

Agitation/psychosis

- Use SSRIs rather than tricyclic antidepressants to treat depression in $\mathrm{AD}$

- Reserve antipsychotics for moderate or severe behavioral and psychological symptoms causing significant distress that have either not responded to other treatments (e.g., nonpharmacologic measures, ChEIs) or when other treatments are not appropriate

Not recommended

- Aspirin should not be used to treat $\mathrm{AD}$, except in those with $\mathrm{AD}$ who also have other indications for its use

- Vitamin E should not be used as a treatment for AD

- Insufficient evidence to support the use of other agents, including anti-inflammatory drugs, selegiline,

estrogens, pentoxifylline, statins, and porcine brain-derived proteolytic peptide fraction
- Evidence remains modest for efficacy of ChEIs for moderate to severe AD

- Available evidence modest for efficacy of memantine for moderate to severe $\mathrm{AD}$

- Slight effect or unclear clinical significance for memantine and ChEI combination therapy

- Mixed evidence for the efficacy of antidepressants to treat depression

- Antipsychotics provide weak benefits for the treatment of psychosis and agitation

- Antipsychotics can be tapered and discontinued without significant signs of withdrawal or return of behavioral symptoms in many patients with $\mathrm{AD}$

- Benefits of SSRI citalopram for agitation in patients shown in single trial, but treatment may be constrained by cardiac AEs

- Alternative agents (including statins, anti-inflammatory drugs, vitamin E, and estrogens) are not generally recommended because of uncertain efficacy and safety

- Combination of a ChEI and memantine is rational and appears to be safe, but there is insufficient evidence to recommend for or against combination

- Valproate should not be used for agitation and aggression in AD

- Insufficient evidence to recommend for or against quetiapine in the management of severe agitation, aggression, and psychosis, and SSRIs or trazodone

in the management of agitated patients

Antipsychotics (e.g., risperidone, olanzapine, aripiprazole) are recommended for severe gitation, aggression, and psychosis if there is risk of harm to the patient and/or others; the potentia benefit must be weighed against the significan risks such as cerebrovascular AEs and mortality

AD, Alzheimer disease; AE, adverse event; APA, American Psychiatric Association; CCCDTD4, 4th Canadian Consensus Conference on the Diagnosis and Treatment of Dementia; ChEI, cholinesterase inhibitor; EAN, European Academy of Neurology; MOA, mechanism of action; PK, pharmacokinetics; SSRI, selective serotonin reuptake inhibitor. *Formerly known as European Federation of Neurological Societies and European Neurological Society. 
Mild to moderate AD

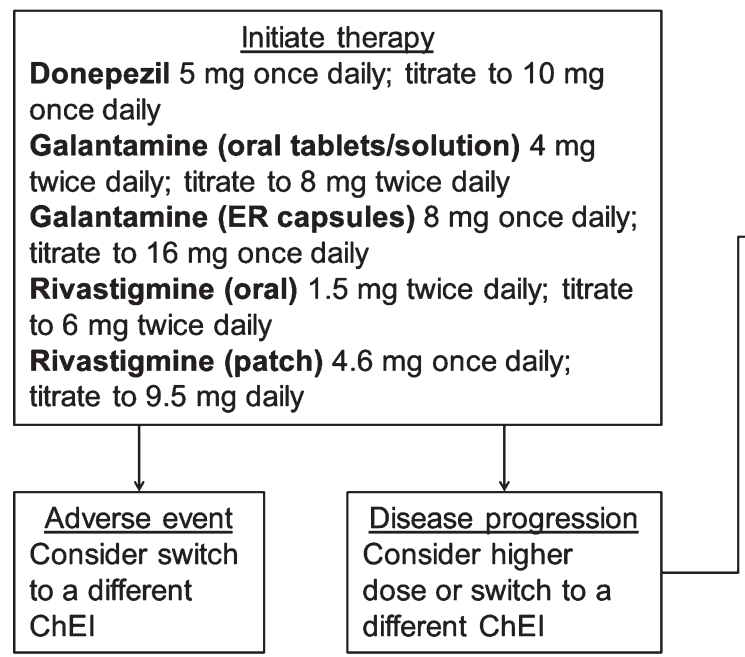

Moderate to severe AD

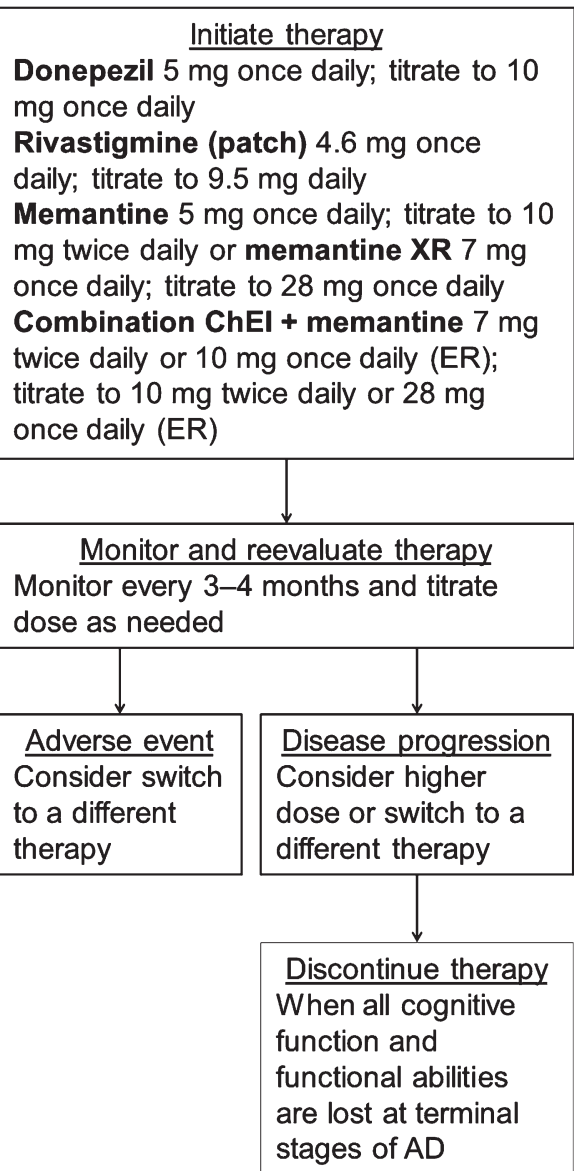

Fig. 1. Treatment algorithm for Alzheimer's disease based on severity of symptoms. AD, Alzheimer's disease; ChEI, cholinesterase inhibitor; ER, extended release; XR, extended release.

associated with dementia is recommended (Table 3), although the available evidence is mixed [33, 75-77]. Similarly, treatment with antipsychotics should be undertaken with caution and only used for moderate or severe agitation, aggression, and psychosis that create significant distress or danger [33, 75-77]. The use of antipsychotics in frail elders with dementia is associated with serious complications, including cerebrovascular AEs and mortality [33, 75]. The mortality rates vary among first-generation (typical) and second-generation (atypical) antipsychotics, and 6-month mortality rates of up to $20 \%$ have been reported in patients with dementia (haloperidol, $20 \%$; olanzapine, $13 \%$; risperidone, $13 \%$; quetiapine, 9\%) [90]. Thus, the potential benefits with antipsychotic treatment should be weighed against risks [91].
The SSRI citalopram has shown treatment benefits at doses of $30 \mathrm{mg} /$ day or greater [92, 93]. In patients with probable $\mathrm{AD}$, citalopram significantly reduced agitation compared with placebo [92]. However, citalopram $30 \mathrm{mg} /$ day was associated with QT interval prolongation, and patients older than 60 should not exceed a daily dose of $20 \mathrm{mg}$ per FDA safety warning, which limits the use of citalopram among patients with $\mathrm{AD}[92,94]$. A recent study reported that citalopram $(60 \mathrm{mg})$ reduced the amyloid- $\beta$ concentration in cerebrospinal fluid in healthy adults and blocked the growth of amyloid plaques in an animal model, suggesting that it may have a disease-modifying role in AD [93]. Additionally, evidence suggests, but does not prove, possible behavioral benefits of donepezil and memantine [47, 95]. Further studies are needed to confirm these 
research findings and address their potential clinical relevance.

\section{ALTERNATIVE THERAPIES}

In general, there is insufficient evidence to support the routine use of other agents, including antiinflammatory drugs, gingko, vitamin E, selegiline, estrogens, pentoxifylline, or statins, for the treatment of $\mathrm{AD}[33,76,77]$. A meta-analysis of dementia treatment strategies performed by Laver et al. reported that selegiline and ginkgo biloba showed statistically significant positive effects across seven studies each; however, the quality of these studies was low (due to risk of bias and inconsistency of results) and very low (due to very serious risk of bias and inconsistency of results), respectively [96]. In contrast, a large, randomized, placebo-controlled study did not show a cognitive or functional benefit for ginkgo biloba in patients with mild to moderate $\mathrm{AD}$; however, the placebo group demonstrated little cognitive or functional decline and, consequently, may have reduced the likelihood of detecting a treatment effect [97]. The aforementioned meta-analysis by Laver et al. also reported that statins had no statistically significant effect across three studies with high-quality evidence [96]. A recent study indicates that statins may prove more effective in individuals with the ApoE4 allele of the apolipoprotein E gene [98], but further evidence is needed to support this finding. Data regarding postmenopausal hormone therapy have been mixed, with a large clinical trial demonstrating an increased risk of cognitive decline with hormone therapy and a 2013 meta-analysis of seven studies finding no overall effect of estrogen therapy on $\mathrm{AD}[99,100]$. Although research continues into the effects of nonsteroidal anti-inflammatory drugs in preventing and treating $\mathrm{AD}$, a meta-analysis demonstrated that the evidence does not support the use of these drugs to improve cognition or reduce AD severity [101]. The AAN 2001 guidelines recommended the use of vitamin $\mathrm{E}$ to slow progression of $\mathrm{AD}$, but the more recently updated APA 2014 and EAN 2010 guidelines do not support this recommendation [33, 76, 77]. Furthermore, there may be some safety concerns with high-dose ( $\geq 400 \mathrm{IU} /$ day) vitamin E supplements [102], although the results of a more recent Veterans Administration (VA) study suggested that vitamin E (2000 IU/day) in combination with a ChEI was well tolerated and effective in slowing functional decline in older men with mild to moderate AD [55].

\section{THERAPIES IN THE PIPELINE}

In recent years, drugs that target the pathobiological processes involved in AD have emerged [103]. These putative disease-modifying therapies aim to slow the progression of AD instead of only addressing its symptoms [103]. Therapies currently in phase III trials that target the amyloid cascade include agents aiming to decrease amyloid- $\beta$ production ( $\beta$ secretase 1 inhibitors or $\gamma$-secretase modulators) or increase amyloid- $\beta$ clearance (anti-amyloid- $\beta$ antibodies or active immunotherapies) [103]. However, to date, all completed phase III trials that have tested these agents (e.g., bapineuzumab, solanezumab, verubecestat) have failed to meet their primary endpoints [104-106]. The failure of anti-amyloid- $\beta$ drugs in $\mathrm{AD}$ has led to the hypothesis that such agents may need to be deployed earlier in the course of illness, before the brain is ravaged, possibly even before symptoms are manifest. Several clinical trials in individuals "at risk" for AD or with preclinical or prodromal $\mathrm{AD}$ are now under way.

In addition to drugs that target the amyloid cascade, drugs that target the tau pathway (tau aggregation inhibitors or anti-tau antibodies), as well as other targets (e.g., tyrosine kinase inhibitor, receptor for advanced glycation end-products inhibitor) are being investigated [103, 107]. Recently, phase III clinical trials of idalopirdine, a serotonin $\left(5-\mathrm{HT}_{6}\right)$ receptor antagonist, failed to meet the primary efficacy endpoint of improving cognitive performance [108]. Targeting multiple pathologic pathways with different drug classes may be required for optimal disease management; this strategy is commonly used for hypertension, diabetes, cancer, and acquired immunodeficiency syndrome treatments [109]. Examples in AD management include an ongoing study of ALZTOP1, which is a combination of the antiamyloid agent cromolyn and the anti-inflammatory agent ibuprofen [110], and a recent trial of solifenacin as an add-on to donepezil therapy [111]. The combination of solifenacin and donepezil increased tolerability versus donepezil alone and may allow for more optimized dosing of donepezil by overcoming AE-related dosing limits [111]. Similarly, repurposing existing drugs that are licensed for other indications, but have the potential to work in $\mathrm{AD}$, may offer viable candidates for disease modification. However, development of future therapies and optimizing treatment may be a challenge until there is a better understanding of underlying disease mechanisms. If one or more disease-modifying therapies become available, 
we predict that there will still be a strong rationale for use of symptomatic therapies. It is unlikely that disease-modifying therapies will prevent symptoms altogether or that disease-modifying therapies will be used exclusively. Because the AD developmental pipeline changes frequently, we have only presented a relatively brief list of therapies. It was our intention to just provide the reader with a sense of the direction as to where this field was headed. Moreover, we believe that the treatments included provide an adequate representation of the many therapeutic approaches that are currently in various phases of development.

\section{CONCLUSIONS}

The current treatment algorithm for $\mathrm{AD}$ is based on the use of ChEIs for mild, moderate, and severe disease and adding memantine for moderate to severe disease. Treatment should be initiated at the time of diagnosis of $\mathrm{AD}$ dementia, the earlier the better, and patients should be monitored for disease progression. Future therapies may optimize currently available drugs and slow the progression of $\mathrm{AD}$ symptoms or even AD pathology. There is also the possibility that future therapies could delay or even prevent emergence of $\mathrm{AD}$ symptoms in those who are at high risk for the disease.

\section{ACKNOWLEDGMENTS}

The authors received medical writing and editorial assistance from the CHC Group (North Wales, PA), which was supported by Lundbeck.

Lundbeck provided funding for medical writing and editorial support in the development of this manuscript.

Authors' disclosures available online (https:// www.j-alz.com/manuscript-disclosures/18-0903r1).

\section{REFERENCES}

[1] Blennow K, de Leon MJ, Zetterberg H (2006) Alzheimer's disease. Lancet 368, 387-403.

[2] Brookmeyer R, Johnson E, Ziegler-Graham K, Arrighi HM (2007) Forecasting the global burden of Alzheimer's disease. Alzheimers Dement 3, 186-191.

[3] Alzheimer's Disease International (2016) World Alzheimer Report 2016. Improving healthcare for people living with dementia: Coverage, quality and costs now and in the future. Summary Sheet. Alzheimer's Disease International https://www.alz.co.uk/research/ worldalzheimerreport2016sheet.pdf, Accessed on June 28,2018
[4] Manuel DG, Garner R, Fines P, Bancej C, Flanagan W, Tu K, Reimer K, Chambers LW, Bernier J (2016) Alzheimer's and other dementias in Canada, 2011 to 2031: A microsimulation Population Health Modeling (POHEM) study of projected prevalence, health burden, health services, and caregiving use. Popul Health Metr 14, 37.

[5] Alzheimer's Association (2016) 2016 Alzheimer's disease facts and figures. Alzheimers Dement 12, 459-509.

[6] Murphy SL, Kochanek KD, Xu J, Heron M (2015) Deaths: Final data for 2012. Natl Vital Stat Rep 63, 1-117.

[7] Bradford A, Kunik ME, Schulz P, Williams SP, Singh H (2009) Missed and delayed diagnosis of dementia in primary care: Prevalence and contributing factors. Alzheimer Dis Assoc Disord 23, 306-314.

[8] Savva GM, Arthur A (2015) Who has undiagnosed dementia? A cross-sectional analysis of participants of the Aging, Demographics and Memory Study. Age Ageing 44, 642-647.

[9] Cordell CB, Borson S, Boustani M, Chodosh J, Reuben D, Verghese J, Thies W, Fried LB, Medicare Detection of Cognitive Impairment Workgroup (2013) Alzheimer's Association recommendations for operationalizing the detection of cognitive impairment during the Medicare Annual Wellness Visit in a primary care setting. Alzheimers Dement 9, 141-150.

[10] Boustani MA, Munger S, Gulati R, Vogel M, Beck RA, Callahan CM (2010) Selecting a change and evaluating its impact on the performance of a complex adaptive health care delivery system. Clin Interv Aging 5, 141-148.

[11] Campos C, Rocha NB, Vieira RT, Rocha SA, TellesCorreia D, Paes F, Yuan T, Nardi AE, Arias-Carrion O, Machado S, Caixeta L (2016) Treatment of cognitive deficits in Alzheimer's disease: A psychopharmacological review. Psychiatr Danub 28, 2-12.

[12] Bent-Ennakhil N, Coste F, Xie L, Aigbogun MS, Wang Y, Kariburyo F, Hartry A, Baser O, Neumann P, Fillit H (2017) A real-world analysis of treatment patterns for cholinesterase inhibitors and memantine among newlydiagnosed Alzheimer's disease patients. Neurol Ther 6, 131-144.

[13] Fisher A, Carney G, Bassett K, Chappell NL (2016) Cholinesterase inhibitor utilization: The impact of provincial drug policy on discontinuation. Value Health 19, 688-696.

[14] Aricept (donepezil hydrochloride). Full Prescribing Information, Eisai Inc., Woodcliff Lake, NJ, 2015.

[15] Razadyne (galantamine hydrobromide). Full Prescribing Information, Janssen Pharmaceuticals Inc., Titusville, NJ, 2016.

[16] Exelon (rivastigmine tartrate). Full Prescribing Information, Novartis Pharmaceuticals Corporation, East Hanover, NJ, 2015.

[17] Mehta M, Adem A, Sabbagh M (2012) New acetylcholinesterase inhibitors for Alzheimer's disease. Int $J$ Alzheimers Dis 2012, 728983.

[18] Watkins PB, Zimmerman HJ, Knapp MJ, Gracon SI, Lewis KW (1994) Hepatotoxic effects of tacrine administration in patients with Alzheimer's disease. JAMA 271, 992-998.

[19] Francis PT, Parsons CG, Jones RW (2012) Rationale for combining glutamatergic and cholinergic approaches in the symptomatic treatment of Alzheimer's disease. Expert Rev Neurother 12, 1351-1365.

[20] Cacabelos R (2007) Donepezil in Alzheimer's disease: From conventional trials to pharmacogenetics. Neuropsychiatr Dis Treat 3, 303-333. 
[21] Heydorn WE (1997) Donepezil (E2020): A new acetylcholinesterase inhibitor. Review of its pharmacology, pharmacokinetics, and utility in the treatment of Alzheimer's disease. Expert Opin Investig Drugs 6, 15271535 .

[22] Ohnishi A, Mihara M, Kamakura H, Tomono Y, Hasegawa J, Yamazaki K, Morishita N, Tanaka T (1993) Comparison of the pharmacokinetics of E2020, a new compound for Alzheimer's disease, in healthy young and elderly subjects. J Clin Pharmacol 33, 1086-1091.

[23] Farlow MR, Salloway S, Tariot PN, Yardley J, Moline ML, Wang Q, Brand-Schieber E, Zou H, Hsu T, Satlin A (2010) Effectiveness and tolerability of high-dose $(23 \mathrm{mg} / \mathrm{d})$ versus standard-dose $(10 \mathrm{mg} / \mathrm{d})$ donepezil in moderate to severe Alzheimer's disease: A 24-week, randomized, double-blind study. Clin Ther 32, 1234-1251.

[24] Exelon Patch (rivastigmine transdermal system). Full Prescribing Information, Novartis Pharmaceuticals Corporation, East Hanover, NJ, 2016.

[25] Kurz A, Farlow M, Lefevre G (2009) Pharmacokinetics of a novel transdermal rivastigmine patch for the treatment of Alzheimer's disease: A review. Int J Clin Pract 63, 799-805.

[26] Lefevre G, Sedek G, Jhee SS, Leibowitz MT, Huang HL, Enz A, Maton S, Ereshefsky L, Pommier F, Schmidli H, Appel-Dingemanse S (2008) Pharmacokinetics and pharmacodynamics of the novel daily rivastigmine transdermal patch compared with twice-daily capsules in Alzheimer's disease patients. Clin Pharmacol Ther 83, 106-114.

[27] Lefevre G, Sedek G, Huang HL, Saltzman M, Rosenberg M, Kiese B, Fordham P (2007) Pharmacokinetics of a rivastigmine transdermal patch formulation in healthy volunteers: Relative effects of body site application. J Clin Pharmacol 47, 471-478.

[28] Tan CC, Yu JT, Wang HF, Tan MS, Meng XF, Wang C, Jiang T, Zhu XC, Tan L (2014) Efficacy and safety of donepezil, galantamine, rivastigmine, and memantine for the treatment of Alzheimer's disease: A systematic review and meta-analysis. J Alzheimers Dis 41, 615-631.

[29] Hansen RA, Gartlehner G, Webb AP, Morgan LC, Moore CG, Jonas DE (2008) Efficacy and safety of donepezil, galantamine, and rivastigmine for the treatment of Alzheimer's disease: A systematic review and meta-analysis. Clin Interv Aging 3, 211-225.

[30] Birks J (2006) Cholinesterase inhibitors for Alzheimer's disease. Cochrane Database Syst Rev, CD005593.

[31] Takeda A, Loveman E, Clegg A, Kirby J, Picot J, Payne E, Green C (2006) A systematic review of the clinical effectiveness of donepezil, rivastigmine and galantamine on cognition, quality of life and adverse events in Alzheimer's disease. Int J Geriatr Psychiatry 21, 17-28.

[32] Cummings J, Jones R, Wilkinson D, Lopez O, Gauthier S, Waldemar G, Zhang R, Xu Y, Sun Y, Richardson S, Mackell J (2010) Effect of donepezil on cognition in severe Alzheimer's disease: A pooled data analysis. J Alzheimers Dis 21, 843-851.

[33] Rabins PV, Rovner BW, Rummans T, Schneider LS, Tariot PN, Guideline watch (October 2014): Practice guideline for the treatment of patients with Alzheimer's disease and other dementias, APA Guideline Watch, http:// psychiatryonline.org/pb/assets/raw/sitewide/practice guidelines/guidelines/alzheimerwatch.pdf, Accessed on September 6, 2018.

[34] Geldmacher DS, Provenzano G, McRae T, Mastey V, Ieni JR (2003) Donepezil is associated with delayed nursing home placement in patients with Alzheimer's disease. J Am Geriatr Soc 51, 937-944.

[35] Beusterien KM, Thomas SK, Gause D, Kimel M, Arcona S, Mirski D (2004) Impact of rivastigmine use on the risk of nursing home placement in a US sample. CNS Drugs 18, 1143-1148.

[36] Feldman HH, Pirttila T, Dartigues JF, Everitt B, Van Baelen B, Schwalen S, Kavanagh S (2009) Treatment with galantamine and time to nursing home placement in Alzheimer's disease patients with and without cerebrovascular disease. Int J Geriatr Psychiatry 24, 479-488.

[37] Courtney C, Farrell D, Gray R, Hills R, Lynch L, Sellwood E, Edwards S, Hardyman W, Raftery J, Crome P, Lendon C, Shaw H, Bentham P, AD2000 Collaborative Group (2004) Long-term donepezil treatment in 565 patients with Alzheimer's disease (AD2000): Randomised double-blind trial. Lancet 363, 2105-2115.

[38] Mohs RC, Doody RS, Morris JC, Ieni JR, Rogers SL, Perdomo CA, Pratt RD, “312” Study Group (2001) A 1year, placebo-controlled preservation of function survival study of donepezil in AD patients. Neurology 57, 481-488.

[39] Winblad B, Wimo A, Engedal K, Soininen H, Verhey F, Waldemar G, Wetterholm AL, Haglund A, Zhang R, Schindler R (2006) 3-year study of donepezil therapy in Alzheimer's disease: Effects of early and continuous therapy. Dement Geriatr Cogn Disord 21, 353-363.

[40] Jones RW (2010) A review comparing the safety and tolerability of memantine with the acetylcholinesterase inhibitors. Int J Geriatr Psychiatry 25, 547-553.

[41] Lampela P, Taipale H, Hartikainen S (2016) Use of cholinesterase inhibitors increases initiation of urinary anticholinergics in persons with Alzheimer's disease. J Am Geriatr Soc 64, 1510-1512.

[42] Jackson S, Ham RJ, Wilkinson D (2004) The safety and tolerability of donepezil in patients with Alzheimer's disease. Br J Clin Pharmacol 58(Suppl 1), 1-8.

[43] Namenda XR (memantine hydrochloride). Full Prescribing Information, Forest Pharmaceuticals Inc., St. Louis, MO, 2014.

[44] Schneider LS, Dagerman KS, Higgins JP, McShane R (2011) Lack of evidence for the efficacy of memantine in mild Alzheimer disease. Arch Neurol 68, 991-998.

[45] Danysz W, Parsons CG (2012) Alzheimer's disease, beta-amyloid, glutamate, NMDA receptors and memantine-searching for the connections. Br J Pharmacol 167, 324-352.

[46] Matsunaga S, Kishi T, Iwata N (2015) Memantine monotherapy for Alzheimer's disease: A systematic review and meta-analysis. PLoS One 10, e0123289.

[47] Doody RS, Tariot PN, Pfeiffer E, Olin JT, Graham SM (2007) Meta-analysis of six-month memantine trials in Alzheimer's disease. Alzheimers Dement 3, 7-17.

[48] Bakchine S, Loft $\mathrm{H}$ (2008) Memantine treatment in patients with mild to moderate Alzheimer's disease: Results of a randomised, double-blind, placebo-controlled 6-month study. J Alzheimers Dis 13, 97-107.

[49] Peskind ER, Potkin SG, Pomara N, Ott BR, Graham SM, Olin JT, McDonald S (2006) Memantine treatment in mild to moderate Alzheimer disease: A 24-week randomized, controlled trial. Am J Geriatr Psychiatry 14, 704-715.

[50] Peters O, Fuentes M, Joachim LK, Jessen F, Luckhaus C, Kornhuber J, Pantel J, Hull M, Schmidtke K, Ruther E, Moller HJ, Kurz A, Wiltfang J, Maier W, Wiese B, Frolich L, Heuser I (2015) Combined treatment with memantine and galantamine-CR compared with galantamine-CR only 
in antidementia drug naive patients with mild-to-moderate Alzheimer's disease. Alzheimers Dement (N Y) 1, 198-204.

[51] Porsteinsson AP, Grossberg GT, Mintzer J, Olin JT, Memantine MEM-MD-12 Study Group (2008) Memantine treatment in patients with mild to moderate Alzheimer's disease already receiving a cholinesterase inhibitor: A randomized, double-blind, placebo-controlled trial. Curr Alzheimer Res 5, 83-89.

[52] Reisberg B, Doody R, Stoffler A, Schmitt F, Ferris S, Mobius HJ, Memantine Study Group (2003) Memantine in moderate-to-severe Alzheimer's disease. N Engl J Med 348, 1333-1341.

[53] Tariot PN, Farlow MR, Grossberg GT, Graham SM, McDonald S, Gergel I, Memantine Study Group (2004) Memantine treatment in patients with moderate to severe Alzheimer disease already receiving donepezil: A randomized controlled trial. JAMA 291, 317-324.

[54] van Dyck CH, Tariot PN, Meyers B, Malca Resnick E, Memantine MEM-MD-01 Study Group (2007) A 24-week randomized, controlled trial of memantine in patients with moderate-to-severe Alzheimer disease. Alzheimer Dis Assoc Disord 21, 136-143.

[55] Dysken MW, Sano M, Asthana S, Vertrees JE, Pallaki M, Llorente M, Love S, Schellenberg GD, McCarten JR, Malphurs J, Prieto S, Chen P, Loreck DJ, Trapp G, Bakshi RS, Mintzer JE, Heidebrink JL, Vidal-Cardona A, Arroyo LM, Cruz AR, Zachariah S, Kowall NW, Chopra MP, Craft S, Thielke S, Turvey CL, Woodman C, Monnell KA, Gordon K, Tomaska J, Segal Y, Peduzzi PN, Guarino PD (2014) Effect of vitamin $\mathrm{E}$ and memantine on functional decline in Alzheimer disease: The TEAM-AD VA cooperative randomized trial. JAMA 311, 33-44.

[56] Jonsson L (2005) Cost-effectiveness of memantine for moderate to severe Alzheimer's disease in Sweden. Am J Geriatr Pharmacother 3, 77-86.

[57] Suzuki H, Inoue Y, Nishiyama A, Mikami K, Gen K (2013) Clinical efficacy and changes in the dosages of concomitantly used psychotropic drugs in memantine therapy in Alzheimer's disease with behavioral and psychological symptoms on dementia. Ther Adv Psychopharmacol 3, 123-128.

[58] Zhang N, Wei C, Du H, Shi FD, Cheng Y (2015) The effect of memantine on cognitive function and behavioral and psychological symptoms in mild-to-moderate Alzheimer's disease patients. Dement Geriatr Cogn Disord 40, 85-93.

[59] Cumbo E, Ligori LD (2014) Differential effects of current specific treatments on behavioral and psychological symptoms in patients with Alzheimer's disease: A 12month, randomized, open-label trial. J Alzheimers Dis 39, 477-485.

[60] Tampi RR, van Dyck CH (2007) Memantine: Efficacy and safety in mild-to-severe Alzheimer's disease. Neuropsychiatr Dis Treat 3, 245-258.

[61] Moritoyo T, Hasunuma T, Harada K, Tateishi T, Watanabe M, Kotegawa T, Nagai M, Kumagai Y, Fujitani T, Okura T, Fukuoka T, Miyoshi K, Matsuura B, Furukawa S, Kobori T, Moritoyo H, Nishikawa N, Tsujii T, Iwaki H, Nakamura M, Makino S, Ohnuma K, Yuji K, Hashimoto M, Takasu M, Hashizume Y, You K, Matsumura T, Tanaka Y, Matsumoto N, Nakamura J, Miura J, Akizawa T, Kitazawa K, Shibata T, Kuroki A, Honda H, Mukai M, Ohashi K, Morimoto T, Imai H, Okudaira T, Sato F, Imanaga J, Tanaka K, Nomoto M (2012) Effect of renal impairment on the pharmacokinetics of memantine. J Pharmacol Sci 119, 324-329.

[62] Periclou A, Ventura D, Rao N, Abramowitz W (2006) Pharmacokinetic study of memantine in healthy and renally impaired subjects. Clin Pharmacol Ther 79, 134143.

[63] Grossberg GT, Manes F, Allegri RF, Gutierrez-Robledo LM, Gloger S, Xie L, Jia XD, Pejovic V, Miller ML, Perhach JL, Graham SM (2013) The safety, tolerability, and efficacy of once-daily memantine (28mg): A multinational, randomized, double-blind, placebo-controlled trial in patients with moderate-to-severe Alzheimer's disease taking cholinesterase inhibitors. CNS Drugs 27, 469-478.

[64] Howard R, McShane R, Lindesay J, Ritchie C, Baldwin A, Barber R, Burns A, Dening T, Findlay D, Holmes C, Hughes A, Jacoby R, Jones R, Jones R, McKeith I, Macharouthu A, O'Brien J, Passmore P, Sheehan B, Juszczak E, Katona C, Hills R, Knapp M, Ballard C, Brown R, Banerjee S, Onions C, Griffin M, Adams J, Gray R, Johnson T, Bentham P, Phillips P (2012) Donepezil and memantine for moderate-to-severe Alzheimer's disease. $N$ Engl J Med 366, 893-903.

[65] Cretu O, Szalontay AS, Chirita R, Chirita V (2008) [Effect of memantine treatment on patients with moderate-tosevere Alzheimer's disease treated with donepezil]. Rev Med Chir Soc Med Nat Iasi 112, 641-645.

[66] Choi SH, Park KW, Na DL, Han HJ, Kim EJ, Shim YS, Lee JH, Expect Study Group (2011) Tolerability and efficacy of memantine add-on therapy to rivastigmine transdermal patches in mild to moderate Alzheimer's disease: A multicenter, randomized, open-label, parallel-group study. Curr Med Res Opin 27, 1375-1383.

[67] NAMZARIC (memantine HCI and donepezil HCI). Full Prescribing Information, Allergan USA, Inc., Irvine, CA, 2016.

[68] Matsunaga S, Kishi T, Iwata N (2014) Combination therapy with cholinesterase inhibitors and memantine for Alzheimer's disease: A systematic review and metaanalysis. Int J Neuropsychopharmacol 18, pyu 115.

[69] Schmidt R, Hofer E, Bouwman FH, Buerger K, Cordonnier C, Fladby T, Galimberti D, Georges J, Heneka MT, Hort J, Laczo J, Molinuevo JL, O'Brien JT, Religa D, Scheltens P, Schott JM, Sorbi S (2015) EFNS-ENS/EAN Guideline on concomitant use of cholinesterase inhibitors and memantine in moderate to severe Alzheimer's disease. Eur J Neurol 22, 889-898.

[70] Atri A, Molinuevo JL, Lemming O, Wirth Y, Pulte I, Wilkinson D (2013) Memantine in patients with Alzheimer's disease receiving donepezil: New analyses of efficacy and safety for combination therapy. Alzheimers Res Ther 5, 6 .

[71] Tsoi KK, Chan JY, Leung NW, Hirai HW, Wong SY, Kwok TC (2016) Combination therapy showed limited superiority over monotherapy for Alzheimer disease: A meta-analysis of 14 randomized trials. JAm Med Dir Assoc 17, 863 e861-868.

[72] Lopez OL, Becker JT, Wahed AS, Saxton J, Sweet RA, Wolk DA, Klunk W, Dekosky ST (2009) Long-term effects of the concomitant use of memantine with cholinesterase inhibition in Alzheimer disease. J Neurol Neurosurg Psychiatry 80, 600-607.

[73] Weycker D, Taneja C, Edelsberg J, Erder MH, Schmitt FA, Setyawan J, Oster G (2007) Cost-effectiveness of memantine in moderate-to-severe Alzheimer's disease patients receiving donepezil. Curr Med Res Opin 23, 1187-1197. 
[74] Atri A, Shaughnessy LW, Locascio JJ, Growdon JH (2008) Long-term course and effectiveness of combination therapy in Alzheimer disease. Alzheimer Dis Assoc Disord 22, 209-221.

[75] Gauthier S, Patterson C, Chertkow H, Gordon M, Herrmann N, Rockwood K, Rosa-Neto P, Soucy JP (2012) Recommendations of the 4th Canadian Consensus Conference on the Diagnosis and Treatment of Dementia (CCCDTD4). Can Geriatr J 15, 120-126.

[76] Hort J, O'Brien JT, Gainotti G, Pirttila T, Popescu BO, Rektorova I, Sorbi S, Scheltens P, EFNS Scientist Panel on Dementia (2010) EFNS guidelines for the diagnosis and management of Alzheimer's disease. Eur J Neurol 17, 1236-1248.

[77] Doody RS, Stevens JC, Beck C, Dubinsky RM, Kaye JA, Gwyther L, Mohs RC, Thal LJ, Whitehouse PJ, DeKosky ST, Cummings JL (2001) Practice parameter: Management of dementia (an evidence-based review). Report of the Quality Standards Subcommittee of the American Academy of Neurology. Neurology 56, 1154-1166.

[78] Dantoine T, Auriacombe S, Sarazin M, Becker H, Pere JJ, Bourdeix I (2006) Rivastigmine monotherapy and combination therapy with memantine in patients with moderately severe Alzheimer's disease who failed to benefit from previous cholinesterase inhibitor treatment. Int J Clin Pract 60, 110-118.

[79] Cummings JL, Isaacson RS, Schmitt FA, Velting DM (2015) A practical algorithm for managing Alzheimer's disease: What, when, and why? Ann Clin Transl Neurol 2, 307-323.

[80] Farlow MR, Grossberg GT, Sadowsky CH, Meng X, Somogyi M (2013) A 24-week, randomized, controlled trial of rivastigmine patch $13.3 \mathrm{mg} / 24 \mathrm{~h}$ versus $4.6 \mathrm{mg} / 24 \mathrm{~h}$ in severe Alzheimer's dementia. CNS Neurosci Ther 19, 745752.

[81] Cummings J, Froelich L, Black SE, Bakchine S, Bellelli G, Molinuevo JL, Kressig RW, Downs P, Caputo A, Strohmaier C (2012) Randomized, double-blind, parallel-group, 48-week study for efficacy and safety of a higher-dose rivastigmine patch $(15$ vs. $10 \mathrm{~cm}(2))$ in Alzheimer's disease. Dement Geriatr Cogn Disord 33, 341-353.

[82] Mayeux R (2010) Clinical practice. Early Alzheimer's disease. $N$ Engl J Med 362, 2194-2201.

[83] Petersen RC, Lopez O, Armstrong MJ, Getchius TSD, Ganguli M, Gloss D, Gronseth GS, Marson D, Pringsheim T, Day GS, Sager M, Stevens J, Rae-Grant A (2018) Practice guideline update summary: Mild cognitive impairment: Report of the Guideline Development, Dissemination, and Implementation Subcommittee of the American Academy of Neurology. Neurology 90, 126-135.

[84] Herrmann N, O'Regan J, Ruthirakuhan M, Kiss A, Eryavec G, Williams E, Lanctot KL (2016) A randomized placebo-controlled discontinuation study of cholinesterase inhibitors in institutionalized patients with moderate to severe Alzheimer disease. J Am Med Dir Assoc 17, 142-147.

[85] Minett TS, Thomas A, Wilkinson LM, Daniel SL, Sanders J, Richardson J, Littlewood E, Myint P, Newby J, McKeith IG (2003) What happens when donepezil is suddenly withdrawn? An open label trial in dementia with Lewy bodies and Parkinson's disease with dementia. Int J Geriatr Psychiatry 18, 988-993.
[86] Singh S, Dudley C (2003) Discontinuation syndrome following donepezil cessation. Int J Geriatr Psychiatry 18, 282-284.

[87] Bidzan L, Bidzan M (2012) Withdrawal syndrome after donepezil cessation in a patient with dementia. Neurol Sci 33, 1459-1461.

[88] Chen JC, Borson S, Scanlan JM (2000) Stage-specific prevalence of behavioral symptoms in Alzheimer's disease in a multi-ethnic community sample. Am J Geriatr Psychiatry 8, 123-133.

[89] Cerejeira J, Lagarto L, Mukaetova-Ladinska EB (2012) Behavioral and psychological symptoms of dementia. Front Neurol 3, 1-21.

[90] Kales HC, Kim HM, Zivin K, Valenstein M, Seyfried LS, Chiang C, Cunningham F, Schneider LS, Blow FC (2012) Risk of mortality among individual antipsychotics in patients with dementia. Am J Psychiatry 169, 71-79.

[91] Reus VI, Fochtmann LJ, Eyler AE, Hilty DM, HorvitzLennon M, Jibson MD, Lopez OL, Mahoney J, Pasic J, Tan ZS, Wills CD, Rhoads R, Yager J (2016) The American Psychiatric Association practice guideline on the use of antipsychotics to treat agitation or psychosis in patients with dementia. Am J Psychiatry 173, 543-546.

[92] Porsteinsson AP, Drye LT, Pollock BG, Devanand DP, Frangakis C, Ismail Z, Marano C, Meinert CL, Mintzer JE, Munro CA, Pelton G, Rabins PV, Rosenberg PB, Schneider LS, Shade DM, Weintraub D, Yesavage J, Lyketsos CG, CitAD Research Group (2014) Effect of citalopram on agitation in Alzheimer disease: The CitAD randomized clinical trial. JAMA 311, 682-691.

[93] Sheline YI, West T, Yarasheski K, Swarm R, Jasielec MS, Fisher JR, Ficker WD, Yan P, Xiong C, Frederiksen C, Grzelak MV, Chott R, Bateman RJ, Morris JC, Mintun MA, Lee JM, Cirrito JR (2014) An antidepressant decreases CSF Abeta production in healthy individuals and in transgenic AD mice. Sci Transl Med 6, 236re234.

[94] US Food and Drug Administration, FDA Drug Safety Communication: Revised recommendations for Celexa (citalopram hydrobromide) related to a potential risk of abnormal heart rhythms with high doses, https://www.fda.gov/Drugs/DrugSafety/ucm297391.htm, Accessed on June 20, 2018.

[95] National Institute for Health and Clinical Excellence (2011) Donepezil, galantamine, rivastigmine and memantine for the treatment of Alzheimer's disease. NICE technology appraisal guidance 217.

[96] Laver K, Dyer S, Whitehead C, Clemson L, Crotty M (2016) Interventions to delay functional decline in people with dementia: A systematic review of systematic reviews. BMJ Open 6, e010767.

[97] Schneider LS, DeKosky ST, Farlow MR, Tariot PN, Hoerr R, Kieser M (2005) A randomized, double-blind, placebocontrolled trial of two doses of Ginkgo biloba extract in dementia of the Alzheimer's type. Curr Alzheimer Res $\mathbf{2}$, 541-551.

[98] Geifman N, Brinton RD, Kennedy RE, Schneider LS, Butte AJ (2017) Evidence for benefit of statins to modify cognitive decline and risk in Alzheimer's disease. Alzheimers Res Ther 9, 10.

[99] O’Brien J, Jackson JW, Grodstein F, Blacker D, Weuve J (2014) Postmenopausal hormone therapy is not associated with risk of all-cause dementia and Alzheimer's disease. Epidemiol Rev 36, 83-103.

[100] Coker LH, Espeland MA, Rapp SR, Legault C, Resnick SM, Hogan P, Gaussoin S, Dailey M, Shumaker SA 
(2010) Postmenopausal hormone therapy and cognitive outcomes: The Women's Health Initiative Memory Study (WHIMS). J Steroid Biochem Mol Biol 118, 304-310.

[101] Miguel-Alvarez M, Santos-Lozano A, Sanchis-Gomar F, Fiuza-Luces C, Pareja-Galeano H, Garatachea N, Lucia A (2015) Non-steroidal anti-inflammatory drugs as a treatment for Alzheimer's disease: A systematic review and meta-analysis of treatment effect. Drugs Aging 32, 139-147.

[102] Miller ER, 3rd, Pastor-Barriuso R, Dalal D, Riemersma RA, Appel LJ, Guallar E (2005) Meta-analysis: Highdosage vitamin E supplementation may increase all-cause mortality. Ann Intern Med 142, 37-46.

[103] Waite LM (2015) Treatment for Alzheimer's disease: Has anything changed? Aust Prescr 38, 60-63.

[104] Egan MF, Kost J, Tariot PN, Aisen PS, Cummings JL, Vellas B, Sur C, Mukai Y, Voss T, Furtek C, Mahoney E, Harper Mozley L, Vandenberghe R, Mo Y, Michelson D (2018) Randomized trial of verubecestat for mild-tomoderate Alzheimer's disease. N Engl J Med 378, 16911703.

[105] Salloway S, Sperling R, Fox NC, Blennow K, Klunk W, Raskind M, Sabbagh M, Honig LS, Porsteinsson AP, Ferris S, Reichert M, Ketter N, Nejadnik B, Guenzler V, Miloslavsky M, Wang D, Lu Y, Lull J, Tudor IC, Liu E, Grundman M, Yuen E, Black R, Brashear HR, Bapineuzumab Clinical Trial Investigators (2014) Two phase 3 trials of bapineuzumab in mild-to-moderate Alzheimer's disease. N Engl J Med 370, 322-333.
[106] Honig LS, Vellas B, Woodward M, Boada M, Bullock R, Borrie M, Hager K, Andreasen N, Scarpini E, LiuSeifert H, Case M, Dean RA, Hake A, Sundell K, Poole Hoffmann V, Carlson C, Khanna R, Mintun M, DeMattos R, Selzler KJ, Siemers E (2018) Trial of solanezumab for mild dementia due to Alzheimer's disease. $N$ Engl J Med 378, 321-330.

[107] Cummings J, Lee G, Mortsdorf T, Ritter A, Zhong K (2017) Alzheimer's disease drug development pipeline: 2017. Alzheimers Dementia (N Y) 3, 367-384.

[108] Atri A, Frolich L, Ballard C, Tariot PN, Molinuevo JL, Boneva N, Windfeld K, Raket LL, Cummings JL (2018) Effect of idalopirdine as adjunct to cholinesterase inhibitors on change in cognition in patients with Alzheimer disease: Three randomized clinical trials. JAMA 319, 130-142.

[109] Dias KS, Viegas C Jr (2014) Multi-target directed drugs: A modern approach for design of new drugs for the treatment of Alzheimer's disease. Curr Neuropharmacol 12, 239255.

[110] AZTherapies, Inc., Safety and efficacy study of ALZTOP1 in subjects with evidence of early Alzheimer's disease (COGNITE), https://clinicaltrials.gov/ct2/ show/NCT02547818, Accessed on April 23, 2018.

[111] Chase TN, Farlow MR, Clarence-Smith K (2017) Donepezil plus solifenacin (CPC-201) treatment for Alzheimer's disease. Neurotherapeutics 14, 405-416. 